\title{
Genetic divergence toward the selection of promising bean progenitors via mixed multivariate models
}

\author{
Cíntia Machado de Oliveira Moulin Carias ${ }^{1}$, José Henrique Soler \\ Guilhen $^{1}$, Tiago de Souza Marçal ${ }^{2}$, Adésio Ferreira', and Marcia Flores da \\ SilvaFerreira ${ }^{1}$ \\ ${ }^{1}$ Universidade Federal do Espírito Santo (UFES), Alto Universitário, Alegre, ES, Brazil. \\ ${ }^{2}$ Universidade Federal de Viçosa, Avenida Peter Henry Rolfs, Viçosa, MG, Brazil.
}

\begin{abstract}
C.M.O.M. Carias, J.H.S. Guilhen, T.S. Marçal, A. Ferreira, and M.F.S. Ferreira. 2018. Genetic divergence towards selection of promising bean progenitors via mixed multivariate models. Cien. Inv. Agr. 45(3): 251-262. The genetic variability present in the bean (Phaseolus vulgaris L.) germplasm that is currently used as an agricultural crop has been shown to be stable in production and is acceptable for human sustenance. Accordingly, to maintain as much of the available variability as possible, this study aimed to examine the genetic divergence in the bean using multivariate analysis to identify the sources of genetic variability and enable breeders to recognize genetic combinations that have a greater chances of success before crossings are performed. This study was conducted in a randomized block design with three replications in the agricultural year 2015. The agronomic traits evaluated were the stem diameter (DIAM) in millimeters, plant height $(\mathrm{PH})$ in centimeters, number of seedsper plant (NS), protein percentage (PROT), height of the first pod (HFP) in centimeters, pod number (PN), grain mass per plant (GM) in $\mathrm{g} \mathrm{plant}^{-1}$, grain yield (GY) in $\mathrm{kg} \mathrm{ha}^{-1}$, and straw yield (SY) in $\mathrm{kg} \mathrm{ha}^{-1}$. To enable selection of the most divergent genotypes, twenty different genotypes were analyzed via clustering according to the average linkage criterion (UPGMA) using a matrix of the mean standardized Euclidean distances and principal component analysis based on the values predicted via a multivariate mixed model. The results obtained in this study revealed a high degree of genetic divergence and allowed the progenies to be allocated into different groups, as well as recommended crossings for future bean breeding programs.
\end{abstract}

Keywords: Breeding, cluster analysis, genetic variability, Phaseolus vulgaris L, REM/BLUP.

\section{Introduction}

According to current projections, our planet may reach nine billion inhabitants by 2050 , with a parallel increase in food demand of $70 \%$ (FAO, 2009).

Received Nov 21, 2017.Accepted Ago16, 2018. Corresponding author: ciintiia@yahoo.com.br
Unfavorably, severe climatic changes at the global scale may occur (FAO, 2014), which may completely alter the production system as we know it. Therefore, novel techniques should be employed to potentiate food production to secure the food supply.

In this regard, genetic breeding constitutes a successfully strategy that has been adopted with 
the aim of generating productive and adapted cultivars that produce high quality products for human consumption.

The bean (Phaseolus vulgaris L.) is a basic food of many populations; in Brazil, seven out of ten people consume bean grains on a daily basis. The bean is a legume of the family Fabaceae, whose importance goes beyond the economic aspect, as it is highly relevant as a human feed and as a source of amino acids (Ribeiro, 2010), potassium, iron, zinc, calcium, copper (Plans et al., 2013; Ribeiro et al., 2012), and soluble and insoluble fibers (Londero et al., 2015).

Brazil is the third largest bean producer worldwide and is responsible for approximately $13 \%$ of the world's bean production, ranking only behind India and Myanmar (FAO, 2015). In the harvest of 2015, 3.4 million tons of beans were produced in Brazil. Thus, the crop has been considered to be promising among all of the legumes cultivated in Brazil. Genetic breeding of the bean plant is one strategy that has been adopted to prevent the culture from becoming uneconomic, with the aim of generating increasingly productive cultivars.

Genetic breeding programs for beans should strive to select genitors while aiming for hybridization and the formation of segregating populations to ultimately provide cultivars with characteristics that are acceptable for consumption and/or industrialization and allows them to adapt to the cultivation regions. Selection based on only one trait is not as interesting as that based on a set of traits; therefore, multivariate analysis constitutes a viable alternative to help breeders work with a set of traits (Dos Santos et al., 2017; Streck et al., 2017).

Another relevant aspect is the study of genetic divergence, both to discriminate promising genitors according to the performance of hybridizations and to identify the genotypes that are most attractive for breeding programs. Genetic divergence is the key to the success of such programs, as it allows larger heterotic effects on the progeny, thus increasing the chances of obtaining superior genotypes in segregating generations (Gonçalves et al., 2016). The application of methodologies that allow the estimation of genetic divergence by means of multivariate techniques promotes successful planning and work strategies in plant breeding (Rao et al., 1981).

Alternatively, a more accurate selection process can be achieved by applying variance components that are estimated by restricted maximum likelihood (REML) and genetic values that are predicted by the best linear unbiased prediction (BLUP) (De Resende et al, 2014). The prediction of genetic values using REML/BLUP has been applied to plant breeding of the bean (Coimbra et al., 2009; Bertoldo et al., 2009; Cruz Baldissera et al., 2012; Torres et al., 2015). This approach allows for a satisfactory interpretation of biological phenomena, thus providing reliable and important information to obtain higher genetic gains in the species undergoing the breeding process.

Based on these considerations, the present work aimed to evaluate the genetic divergence among bean genotypes via multivariate mixed models to facilitate the selection of promising progenitors for hybridization.

\section{Material and Methods}

Seeds from 20 different genotypes were acquired from commercial cultivars (14) and local varieties (6). The commercial cultivars were selected based on information from the literature regarding their high grain yield, upright aspect, precociousness, and drought tolerance. Local varieties were obtained from producers who have cultivated beans over generations in the state of Espírito Santo (Brazil), with the aim of selecting beans that have some of the agronomic traits cited above, particularly resistance to biotic and abiotic factors. The employed bean genotypes are listed in Table 1 . 
Table 1. Identification, common name, region of origin and seed type of bean (Phaseolus vulgaris L.) genotypes.

\begin{tabular}{|c|c|c|c|c|c|c|}
\hline ID & NAME & M & $\mathrm{TC}$ & CHARACTERISTICS & RESISTANCE & $\mathrm{P}$ \\
\hline G1 & CNFC 15475 & EL & $\mathrm{C}$ & & & \\
\hline G2 & CNFC 15625 & EL & $\mathrm{C}$ & & & \\
\hline G3 & CNFC 15462 & EL & $\mathrm{C}$ & & & \\
\hline G4 & Pérola & EC & $\mathrm{C}$ & $\begin{array}{l}\text { Normal cycle; High } \\
\text { productivepotential; High } \\
\text { grainanduprightbearing }\end{array}$ & Intermediatereactionto angular spot andrust & $\mathrm{AE}$ \\
\hline G5 & BRS Nótavel & $\mathrm{EC}$ & $\mathrm{C}$ & $\begin{array}{l}\text { Semiprecocecycle; High } \\
\text { productivepotential; } \\
\text { Stabilityofproduction; Light } \\
\text { grains }\end{array}$ & $\begin{array}{l}\text { Anthracnose, fusariumwilt, common } \\
\text { bacterialblightandshortbitewiltrium }\end{array}$ & $\mathrm{AE}$ \\
\hline G6 & BRS Estilo & $\mathrm{EC}$ & $\mathrm{C}$ & $\begin{array}{c}\text { Normal cycle; } \\
\text { Adaptedmechanicalharvesting; } \\
\text { High productivepotential; } \\
\text { Stabilityofproduction }\end{array}$ & $\begin{array}{l}\text { Moderatelyresistanttoanthracnose, } \\
\text { rustandbacterialblight }\end{array}$ & $\mathrm{AE}$ \\
\hline G7 & IPR Colibri & $\mathrm{EC}$ & $\mathrm{C}$ & EarlyCycle; Porte erectplant & Common mosaic & $\mathrm{AE}$ \\
\hline G8 & CNFC 15310 & EL & $\mathrm{B}$ & & & \\
\hline G9 & CNFP 15304 & EL & $\mathrm{B}$ & & & \\
\hline G10 & CNFP 15290 & EL & $\mathrm{B}$ & & & \\
\hline G11 & Capixaba Precoce & IC & $\mathrm{B}$ & EarlyCycle & Anthracnoseand bacteriose tolerance & $\mathrm{AE}$ \\
\hline G12 & IPR Uirapuru & IC & B & $\begin{array}{c}\text { Mediumcycle; Standingcarrier; } \\
\text { High productivepotential; } \\
\text { Wideadaptation }\end{array}$ & $\begin{array}{c}\text { ResistanceRust, Oídiumand Common } \\
\text { Mosaic }\end{array}$ & $\mathrm{AE}$ \\
\hline G13 & BRS Campeiro & EC & $\mathrm{B}$ & $\begin{array}{l}\text { Semi-precociouscycle; } \\
\text { Standingcarrier; High } \\
\text { productivepotential }\end{array}$ & $\begin{array}{l}\text { Beddingresistance; Common mosaic; } \\
\text { Intermediateresistancetorustandfuasarium }\end{array}$ & $\mathrm{AE}$ \\
\hline G14 & BRS Esplendor & EC & B & Normal cycle; Porte erectplant & $\begin{array}{l}\text { Resistancelodging, common mosaicand } \\
\text { new typesoffungicausinganthracnose, } \\
\text { tolerancetofusariumwiltandcrusting }\end{array}$ & $\mathrm{AE}$ \\
\hline G15 & Bico de Ouro & FL & $\mathrm{R}$ & & & \\
\hline G16 & Vagem Riscada & FL & $\mathrm{B}$ & & & \\
\hline G17 & Preto Hort & FL & $\mathrm{B}$ & & & \\
\hline G18 & Macuquinho & FL & $\mathrm{Br}$ & & & \\
\hline G19 & Verde & FL & G & & & \\
\hline G20 & Carioca & FL & $\mathrm{C}$ & & & \\
\hline
\end{tabular}

Identification: ID; Material: M; Commercial Type: TC; Public: P; Embrapa/linhagem: EL; Embrapa/cultivar: EC; fairs/landrace: FL; Incaper/cultivar: IC;Carioca: C; Black: B; Red: R; Brown: Br; Green: G; Farmers and Company: AE.

The genotypes selected at this step were subjected to a competition assay in the fields of São Francisco Farm, Alegre-ES. The experiment followed a randomized block design, with three repetitions and plots consisting of four $4 \mathrm{~m}$-long lines, with $0.5 \mathrm{~m}$ between rows and 12 seeds per linear meter, for a total area of $3 \mathrm{~m}^{2}$. Crop handling was carried out according to the recommendations available for the culture (Vieira et al., 2006; Prezotti et al., 2007).
The nine morphoagronomical traits evaluated in the experiment were the stem diameter (DIAM) in millimeters, plant height $(\mathrm{PH})$ in centimeters, number of seeds per plant (NS), protein percentage (PROT), height of the first pod (HFP) in centimeters, pod number (PN), grain mass per plant (GM) in grams plant ${ }^{-1}$, grain yield (GY) in kilograms hectare ${ }^{-1}$ and straw yield (SY) in kilograms hectare-1 (Collicchio et al., 1997; Nietzsche, 2000). 
The assessed traits, DIAM, PH, NS, PROT, HFP and $\mathrm{PN}$, refer to the individual phenotypic value of ten plants inside in a plot, whereas GM, GY and SY were analyzed at the level of the mean plot value.
The traits were subjected to an analysis of mixed models via REML/BLUP using the AI algorithm (Gilmouret et al., 1995) according to the modeling methodology of the expanded matrix form for multiple traits:

$$
\left[\begin{array}{c}
\mathrm{y}_{1} \\
\mathrm{y}_{2} \\
\mathrm{y}_{3} \\
\vdots \\
\mathrm{y}_{\mathrm{n}}
\end{array}\right]=\left[\begin{array}{ccccc}
\mathrm{X}_{1} & 0 & 0 & \cdots & 0 \\
0 & \mathrm{X}_{2} & 0 & \cdots & 0 \\
0 & 0 & \mathrm{X}_{3} & \cdots & 0 \\
\vdots & \vdots & \vdots & \ddots & \vdots \\
0 & 0 & 0 & \cdots & \mathrm{X}_{\mathrm{n}}
\end{array}\right]\left[\begin{array}{c}
\beta_{1} \\
\beta_{2} \\
\beta_{3} \\
\vdots \\
\beta_{\mathrm{n}}
\end{array}\right]+\left[\begin{array}{ccccc}
\mathrm{Z}_{1} & 0 & 0 & \cdots & 0 \\
0 & \mathrm{Z}_{2} & 0 & \cdots & 0 \\
0 & 0 & \mathrm{Z}_{3} & \cdots & 0 \\
\vdots & \vdots & \vdots & \ddots & \vdots \\
0 & 0 & 0 & \cdots & \mathrm{Z}_{\mathrm{n}}
\end{array}\right]\left[\begin{array}{c}
\mathrm{g}_{1} \\
\mathrm{~g}_{2} \\
\mathrm{~g}_{3} \\
\vdots \\
\mathrm{g}_{\mathrm{n}}
\end{array}\right]+\left[\begin{array}{c}
\varepsilon_{1} \\
\varepsilon_{2} \\
\varepsilon_{3} \\
\vdots \\
\varepsilon_{\mathrm{n}}
\end{array}\right]
$$

The compact matrix form for multiple traits:

$$
\mathrm{y}=\mathrm{X} \beta+\mathrm{Zg}+\varepsilon
$$

The structure of the means and covariance matrix:

$$
\begin{gathered}
{\left[\begin{array}{l}
\mathrm{g} \\
\varepsilon
\end{array}\right] \sim \mathrm{N}\left(0,\left[\begin{array}{cc}
\mathrm{G} & 0 \\
0 & \mathrm{R}
\end{array}\right]\right)} \\
\mathrm{G}=\left[\begin{array}{cccc}
\sigma_{\mathrm{g}_{11}}^{2} & \sigma_{\mathrm{g}_{12}} & \cdots & \sigma_{\mathrm{g}_{1 j}} \\
\sigma_{\mathrm{g}_{21}} & \sigma_{\mathrm{g}_{22}}^{2} & \cdots & \sigma_{\mathrm{g}_{2 \mathrm{j}}} \\
\vdots & \vdots & \ddots & \vdots \\
\sigma_{\mathrm{g}_{\mathrm{i}}} & \sigma_{\mathrm{g}_{\mathrm{i} 2}} & \cdots & \sigma_{\mathrm{g}_{\mathrm{ij}}}^{2}
\end{array}\right] \mathrm{R}=\left[\begin{array}{cccc}
\sigma_{\varepsilon_{11}}^{2} & \sigma_{\varepsilon_{12}} & \cdots & \sigma_{\varepsilon_{1 j}} \\
\sigma_{\varepsilon_{21}} & \sigma_{\varepsilon_{22}}^{2} & \cdots & \sigma_{\varepsilon_{2 \mathrm{j}}} \\
\vdots & \vdots & \ddots & \vdots \\
\sigma_{\varepsilon_{i 1}} & \sigma_{\varepsilon_{\mathrm{i} 2}} & \cdots & \sigma_{\varepsilon_{\mathrm{ij}}}^{2}
\end{array}\right]
\end{gathered}
$$

The mixed models equations system:

$$
\left[\begin{array}{cc}
X^{\prime} R^{-1} X & Z^{\prime} R^{-1} X \\
X^{\prime} R^{-1} Z & Z^{\prime} R^{-1} Z+G^{-1}
\end{array}\right]\left[\begin{array}{l}
\hat{\beta} \\
\tilde{g}
\end{array}\right]=\left[\begin{array}{c}
X^{\prime} R^{-1} y \\
Z^{\prime} R^{-1} y
\end{array}\right]
$$

where $y$ is the vector of the observed data, $\beta$ is the vector of the block effects that are assumed to be fixed and are added to the general mean, $g$ is the vector of the genotypic effects that are assumed to be random, $\varepsilon$ is the vector of the random errors, $\mathrm{X}$ is the incidence matrix for the fixed effects, $\mathrm{Z}$ is the incidence matrix for the genotypic effects, $G$ is the matrix of genetic covariance among $\mathrm{i}$ traits, and $\mathrm{R}$ is the matrix of environmental covariance among i traits.

Analysis of genetic divergence was performed through clustering by the average linkage criterion (UPGMA) using the matrix of the mean standard- 
ized Euclidean distances and principal component method and based on the genetic values predicted via a multivariate mixed model, with the aim of selecting the most divergent genotypes.

All analyses were performed with the computational application R (R Core Team, 2016).

\section{Results and Discussion}

The likelihood ratio test detected significant genetic variation among the bean lines for the various studied agronomic traits at a $1 \%$ probability level for individual and plot-adjusted models (Table 2). Therefore, genetic variation was assessed as existing among the tested bean lines, both for the traits sampled in individual plants within the plot (DIAM, PH, NS, PN and GM) and for those obtained from the total set of plants in the allotment (GY, SY and PROT) (Table 2).

Table 2. Analysis of deviance for the agronomic traits measured individually in the plots (Individual) and for those representing the totality of the plot (Plot).

\begin{tabular}{lcccc}
\hline \multirow{2}{*}{ Effect } & \multicolumn{2}{c}{ Individual $^{\dagger}$} & \multicolumn{2}{c}{ Plot $^{\star}$} \\
\cline { 2 - 5 } & Deviance & LRT & Deviance & LRT \\
\hline Genotypes & 10993.10 & $528.96^{* *}$ & 1682.70 & $24.87^{* *}$ \\
Complete model & 10464.14 & --- & 1657.84 & --- \\
\hline
\end{tabular}

'Stem diameter (DIAM) in mm; plant height (PH) in cm; number of seeds (NS); height of the first pod (HFP) in cm; number of pods (PN); grain mass per plant (GM) in $g$ plant ${ }^{-1}$. ${ }^{\ddagger}$ Grain yield (GY) in $\mathrm{Kg} \mathrm{ha}^{-1}$; straw yield (SY) in $\mathrm{Kg} \mathrm{ha}^{-1}$; percentage of protein (PROT). LRT: Likelihood ratio test. $* * \mathrm{p} \leq 0.01$.
The above results are essential for effective selection, as genetic heterogeneity was verified among the lines in the group; hence, the observed phenotypic variation sis not receive contributions exclusively from the environment (Vivas et al., 2015). Moreover, the genotypic contrast among bean lineages for multiple agronomic attributes is a fundamental condition for the planning of crossings in breeding programs that aim at generating variability; that is, selection factors derived from these genotypic contrasts can be used by breeders when they attempt to develop new cultivars (Torres et al., 2015).

Nevertheless, as observed in Table 3, environmental variation strongly contributed to the phenotypic variation of the studied quantitative traits, which promoted low heritability in a broad sense. This effect is quite common for quantitative attributes, which are controlled by many genes, with the phenotypes being greatly influenced by the environment.

The heritability estimated in the total plot showed a lower contribution from the environment to the phenotypic variation $(\mathrm{GY}=0.38$; $\mathrm{SY}=0.41$; $\mathrm{PROT}=0.37)$ than those sampled individually in the plot (DIAM=0.20; HFP $=0.31 ; \mathrm{PH}=0.23$; $\mathrm{PH}=0.08$; NS=0.12; $\mathrm{GM}=0.14$ ) (Table 3), revealing that the selection of these traits may be more effective at the level of the plot mean. Heritability in the genetic study of a trait has a predictive role, expressing the reliability with which the

Table 3. Broad-sense heritability estimation $\left(\hat{\mathrm{h}}_{\mathrm{g}}^{2}\right)$, environmental coefficient of determination $\left(\hat{\mathrm{c}}_{\mathrm{a}}^{2}\right)$, and mean selective accuracy $\left(\hat{\mathrm{r}}_{\mathrm{gg}}\right)$ for the agronomic traits measured individually in the plots (Individuals) and for those representing the total plot (Plot).

\begin{tabular}{lccccccccc}
\hline \multirow{2}{*}{ Parameters } & \multicolumn{9}{c}{ Individual $^{\dagger}$} \\
\cline { 2 - 10 } & DIAM & HFP & PH & PN & NS & GM & GY & SY & PROT \\
\hline$\hat{\mathrm{h}}_{\mathrm{g}}^{2}$ & 0.20 & 0.31 & 0.23 & 0.08 & 0.12 & 0.14 & 0.38 & 0.41 & 0.37 \\
$\hat{\mathrm{c}}_{\mathrm{a}}^{2}$ & 0.80 & 0.69 & 0.77 & 0.92 & 0.88 & 0.86 & 0.62 & 0.59 & 0.63 \\
$\hat{\mathrm{r}}_{\mathrm{gg}}$ & 0.92 & 0.93 & 0.93 & 0.86 & 0.88 & 0.88 & 0.81 & 0.81 & 0.81 \\
\hline
\end{tabular}

${ }^{\dagger}$ Stem diameter (DIAM) in $\mathrm{mm}$; height of the first pod (HFP) in $\mathrm{cm}$; plant height $(\mathrm{PH})$ in $\mathrm{cm}$; number of pods (PN); number of seeds (NS); grain mass per plant (GM) in $g$ plant ${ }^{-1} .{ }^{\ddagger}$ Grain yield (GY) in $\mathrm{Kg} \mathrm{ha}^{-1}$; straw yield (SY) in $\mathrm{Kg} \mathrm{ha}^{-1}$; percentage of protein (PROT). 
phenotypic value represents the genetic value (Silva et al., 2013).

According to Fehr (1987), elevated heritability is associated with a greater additive genetic variance, lower environmental variation, and smaller interaction between the genotype and environment. However, the trait pod number (PN), number of seeds (NS), grain mass per plant (GM) and stem diameter (DIAM) presented results that differed from those of the other variables, indicating a marked environmental influence on these characteristics, thus exposing their complexity (Zilio et al., 2011; Torga et al., 2013; De Faria et al., 2014).

Nevertheless, despite the low heritability values, the mean selective accuracy value $\left(\hat{\mathrm{r}}_{\mathrm{gg}}\right)$ varied between 0.81 and 0.93 for the variables sampled in individual plants in the plot as well as in the set of plants constituting the plot. In this way, the adequacy of the prediction of genotypic values was attested, leading to a greater precision for selection in the studied bean lines (Table 3). According to De Resende and Duarte (2007), selective accuracy values above $80 \%$ should be pursued and assays with selective accuracy inferior to $60 \%$ should not be utilized.

Selection accuracy refers to the correlation between the predicted genetic values and real values of individuals. This correlation aims to corroborate the correct ranking of the cultivars for selection purposes as well as for the efficaciousness of inferring the genotypic value of the cultivar, which is possible because selection accuracy depends not only on the magnitude of the residual variation and number of repetitions but also on the proportion of the variation of the genetic and residual nature that are associated with the evaluated trait (De Resende, 2002; De Resende and Duarte, 2007).

Figure 1 shows the disparate response of the genotypes for the evaluated traits; this type of evaluation is becoming an essential condition for breeders to exert an artificial selection pressure and achieve superior genotypes. The variability detected in the evaluated population is of utmost importance when breeding programs begin, as this type of variability allows selection and crossing according to the breeder's interests (Silva et al., 2014).

The G20, G14, G6 and G3 genotypes contributed the most for the identification of promising genotypes regarding PN, PROT, NS and PH. In turn, G19 presented higher yields of grain and straw (Figure 1). These observations are evidence of the existence of variations in the genetic effects predicted for the studied traits; hence, they will
A

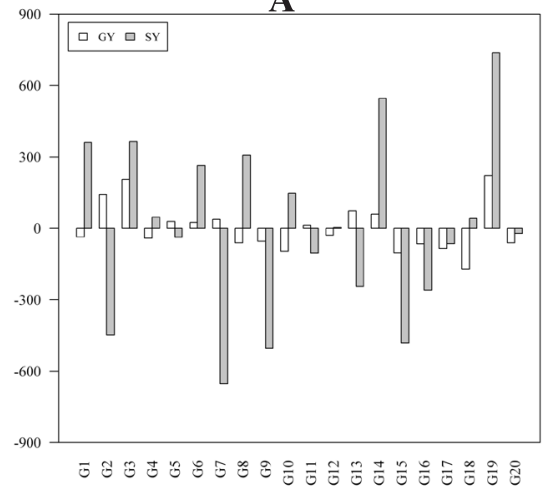

B

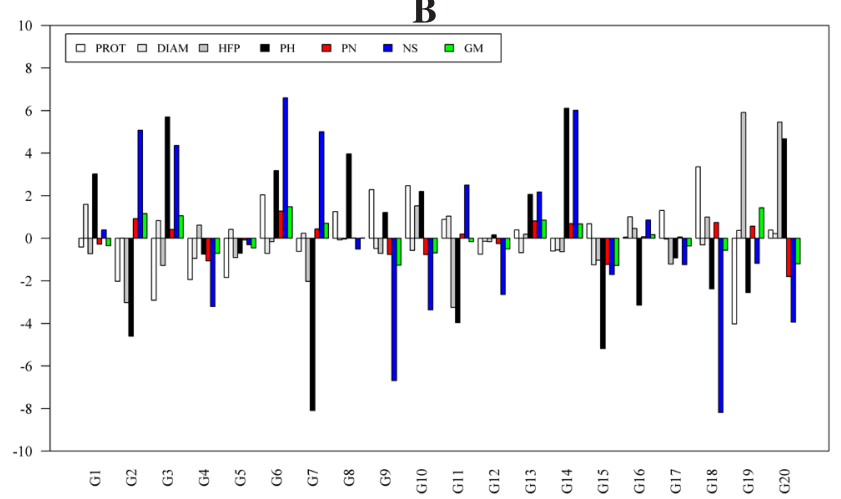

Figure 1. Genetic divergence among the 20 genotypes of Phaseolus vulgaris $\mathrm{L}$. for nine agronomic traits through predicted genetic effects (BLUP) in terms of the deviation from the mean and according to the multivariate model. The following traits can be observed: stem diameter (DIAM) in $\mathrm{mm}$, plant height $(\mathrm{PH})$ in $\mathrm{cm}$, number of seeds (NS), protein percentage (PROT), height of the first pod (HFP) in $\mathrm{cm}$, number of pods (PN), and grain mass per plant (GM) in $\mathrm{g}^{\text {plant }}{ }^{-1}$ [Figure A]; grain yield (GY) in $\mathrm{kg} \mathrm{ha}^{-1}$ and straw yield (SY) in $\mathrm{kg} \mathrm{ha}^{-1}$ [Figure B]. 
serve as the basis for breeders who seeks individuals that concentrate favorable alleles to generate segregating populations that will produce superior recombinants.

The estimates for genetic and phenotypic correlations among the evaluated traits are included in Figure 2. The values for the positive genetic and phenotypic correlations for all of the traits varied from 0.0 to 0.85 ; a coefficient of correlation of zero does not imply a lack of relation between two variables, but reflects the absence of a linear relation between the evaluated traits (Cruz and Regazzi, 1997).

For the trait grain yield, the estimates of the genetic and phenotypic correlations were overall highly significant and positive, except for the height of the first pod (HFP), percentage of protein (PROT), plant height (PH) and number of seeds (NS) (Figure 2). Thus, if selection occurs in favor of HFP, the genetic and phenotypic relationship will be unfavorable to the other production components. For Ramalho et al. (1993), the correlation between traits is a very important parameter, as it makes plant breeders aware that the modifications that occur in a certain trait may result from the selection of another trait correlated to it.

The genetic and phenotypic correlations among certain traits such as the number of seeds, number of pods and grain mass presented values that were positive and superior to those of the others. Thus, the selection of plants for these traits will promote larger production gains than the selection of more productive plants. According to Barili et al. (2016), higher productivity levels are associated with an increased number of pods per plant, number of grains per pod, and number of locules per pod.

The protein content and grain yield traits presented a negative genotypic correlation $(-0.79)$. However, direct selection for the grain yield trait or indirectly via the production components NS or

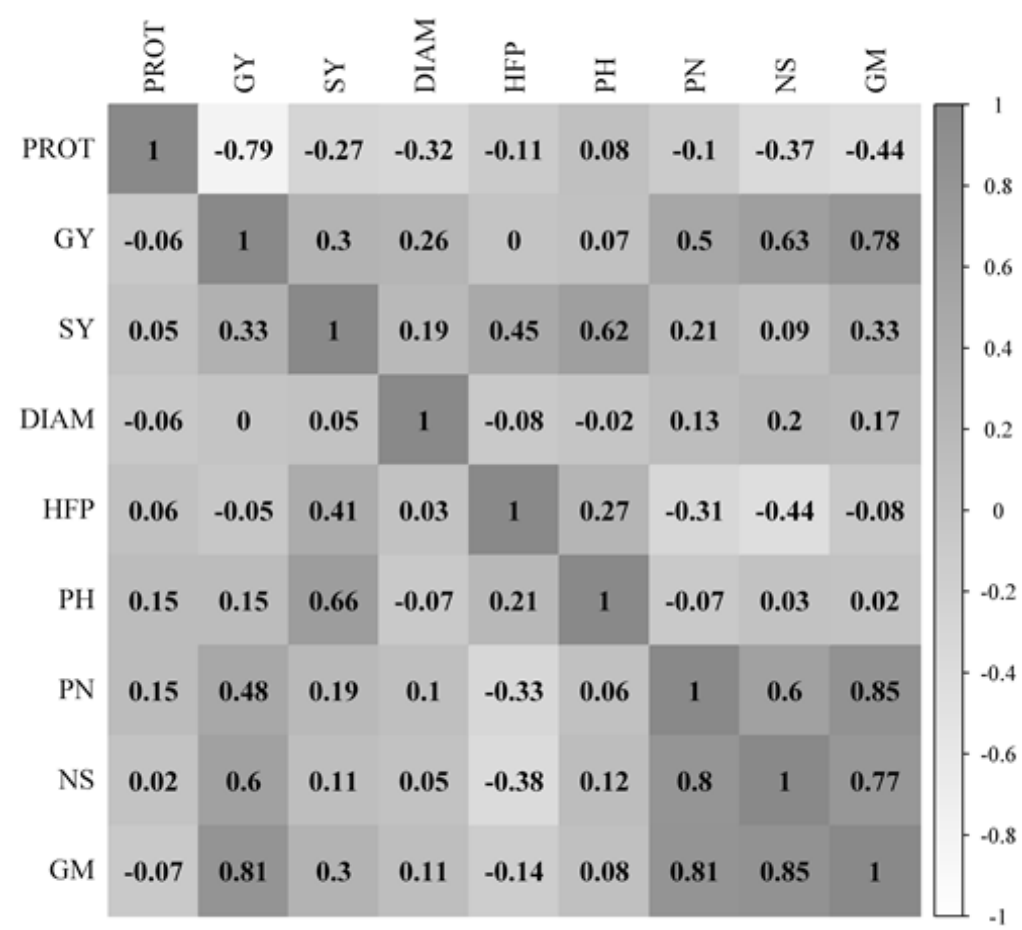

Figure 2. Matrix of the genetic (above the diagonal) and phenotypic correlations (below the diagonal) for nine agronomic traits of 20 Phaseolus vulgaris L. genotypes. The following traits are observed: protein percentage (PROT), grain yield (GY) in $\mathrm{kg} \mathrm{ha}^{-1}$ and straw yield (SY) in $\mathrm{kg}$ $\mathrm{ha}^{-1}$, stem diameter (DIAM) in mm, height of the first pod (HFP) in $\mathrm{cm}$, plant height (PH) in $\mathrm{cm}$, number of pods (PN), number of seeds (NS), and grain mass per plant (GM) in g plant ${ }^{-1}$. 
GM has a negative impact on the protein content of the grains, indicating the low importance of this trait for selection. Hence, the breeder should be careful to consider these correlations when directing the selection of plants.

In the analysis of genetic divergence shown in Figure 3, the most distant genotypes shown in Figure $3 \mathrm{~A}$ for eight agronomic traits were discarded in Figure 3B according to the three first principal components obtained from the matrix of correlation between the predicted genetic values. The genotypes at the center of the figure are the most similar; hence, they are not recommended for application in genetic breeding programs based on hybridization; to include them might restrict the genetic variability, which would render the gains obtained with the selection infeasible (Correa and Gonçalves, 2012). Nevertheless, promising hybridizations should be planned between dissimilar genotypes that present a superior performance for the desirable traits, highlighting the four genotypes removed for the analysis of Figure 3B in addition to G3, G11 and G18.

The distribution of the genotypes in the dendrogram reveals the formation of five groups, with G3, G11 and G18 belonging to distinct groups, which allows their use for crossings. Crossings between diverging genitors that exhibit a superior performance for the desirable traits, such as precociousness, are recommended (Lucena and Dantas, 2017).

In Figure 4B, the formation of three groups composed of a single genotype (G3, G11 and G18) was observed. This result is similar to that shown in Figure 3 (B); that is, the results shown in Figures $3 \mathrm{~B}$ and $4 \mathrm{~B}$ are similar.

The existence of genetic diversity as observed in the analyses informs, in a multivariate manner, that a capacity for advancement exists in breeding programs using the evaluated database. According to Falconer (1987), variability is one of the key factors for the formation of populations with selection potential. In addition, Ramalho et al. (1993) affirmed that hybridization in progenitors with desired or potential trait responses results in improved progenies.

For the selection of the most suitable genitors those that are capable of generating productive populations application of the REML/BLUP methodology allows the ranking of the potential
A

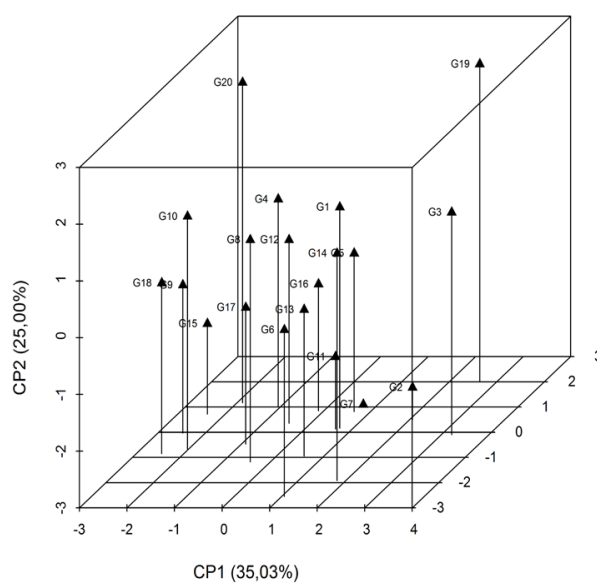

B

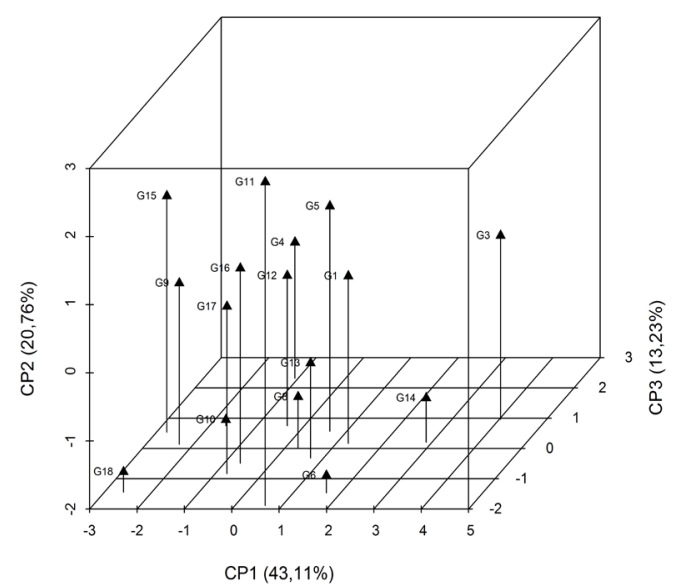

Figure 3. Genetic divergence among 20 (A) and 16 (B) genotypes of Phaseolus vulgaris L. for eight agronomic traits according to the first three principal components obtained from the matrix of correlation between the predicted genetic values. 

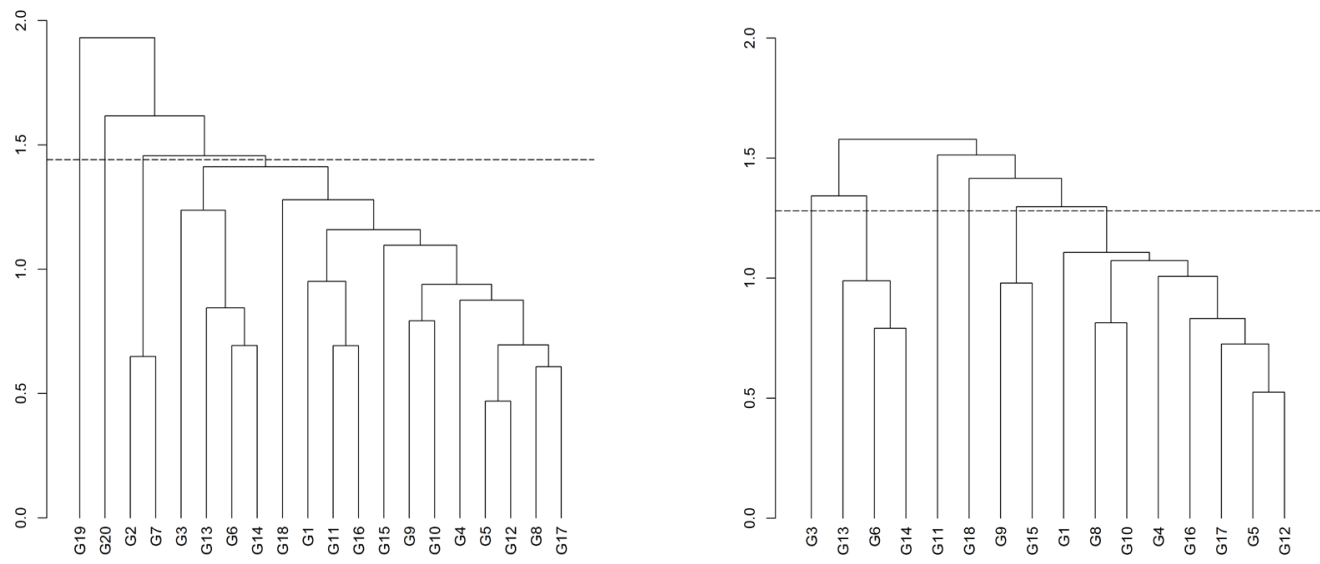

Figure 4. Genetic divergence among 20 (A) and 16 (B) genotypes of Phaseolus vulgaris L. for eight agronomic traits via clustering by the average linkage criterion (UPGMA) using the mean standardized Euclidean distance matrix, obtained from the predicted genetic values.

genotypes, exploring the entire genotypic variation while considering each analyzed trait separately. Thus, crossings involving G2, G3 and G19 will have high contributions to GY (BLUP=142.70;
204.66; 222.39). Moreover, gains are expected in NS (BLUP=0.01; 0.83; 0.37), PN (BLUP=0.92; $0.42 ; 0.57)$ and GM (BLUP=1.16; 1.06; 1.43), as they correlate positively to GY (Figures 5 and 6 ).
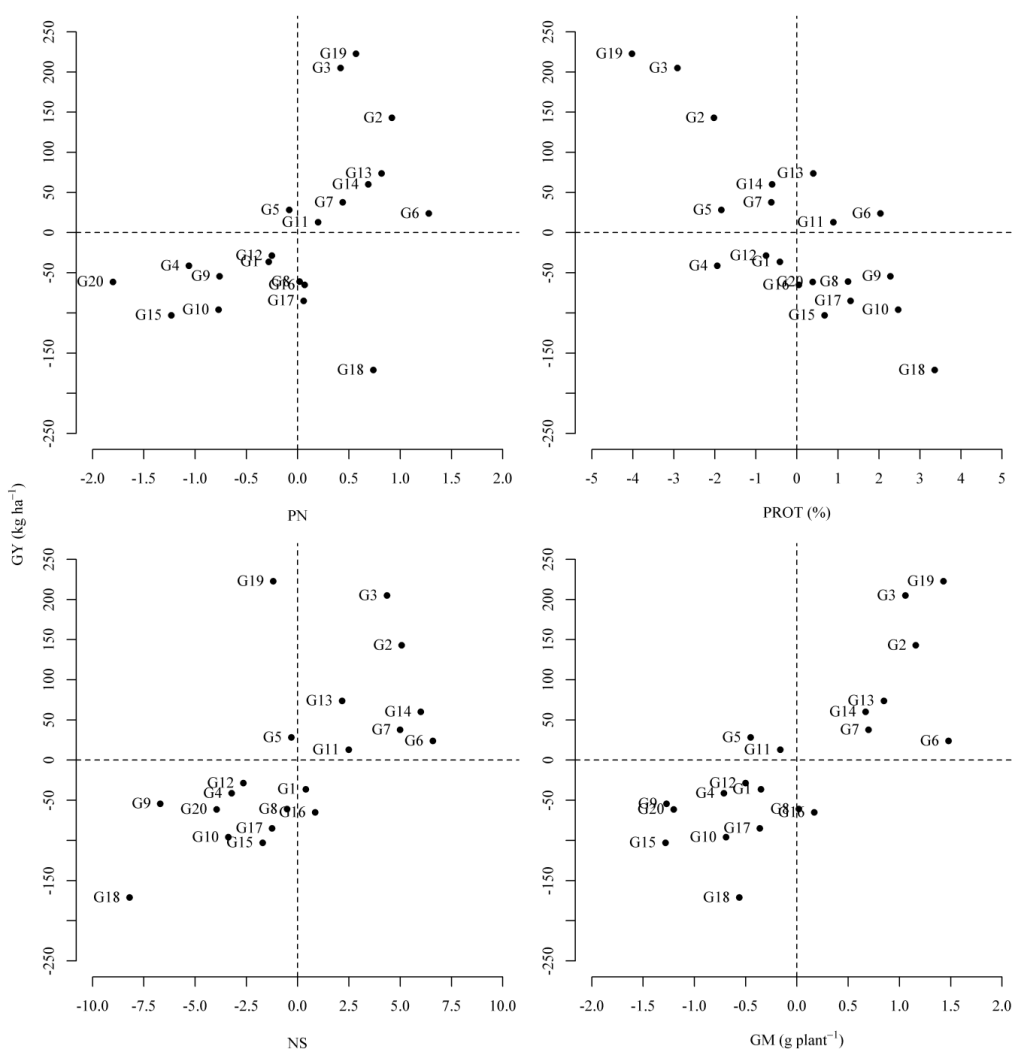

Figure 5. Genotypic values predicted (BLUP) for nine agronomic traits of the 20 Phaseolus vulgaris L. genotypes. Number of pods (PN); number of seeds (NS); protein percentage (PROT); grain mass per plant (GM) in $\mathrm{g} \mathrm{plant}^{-1}$. 

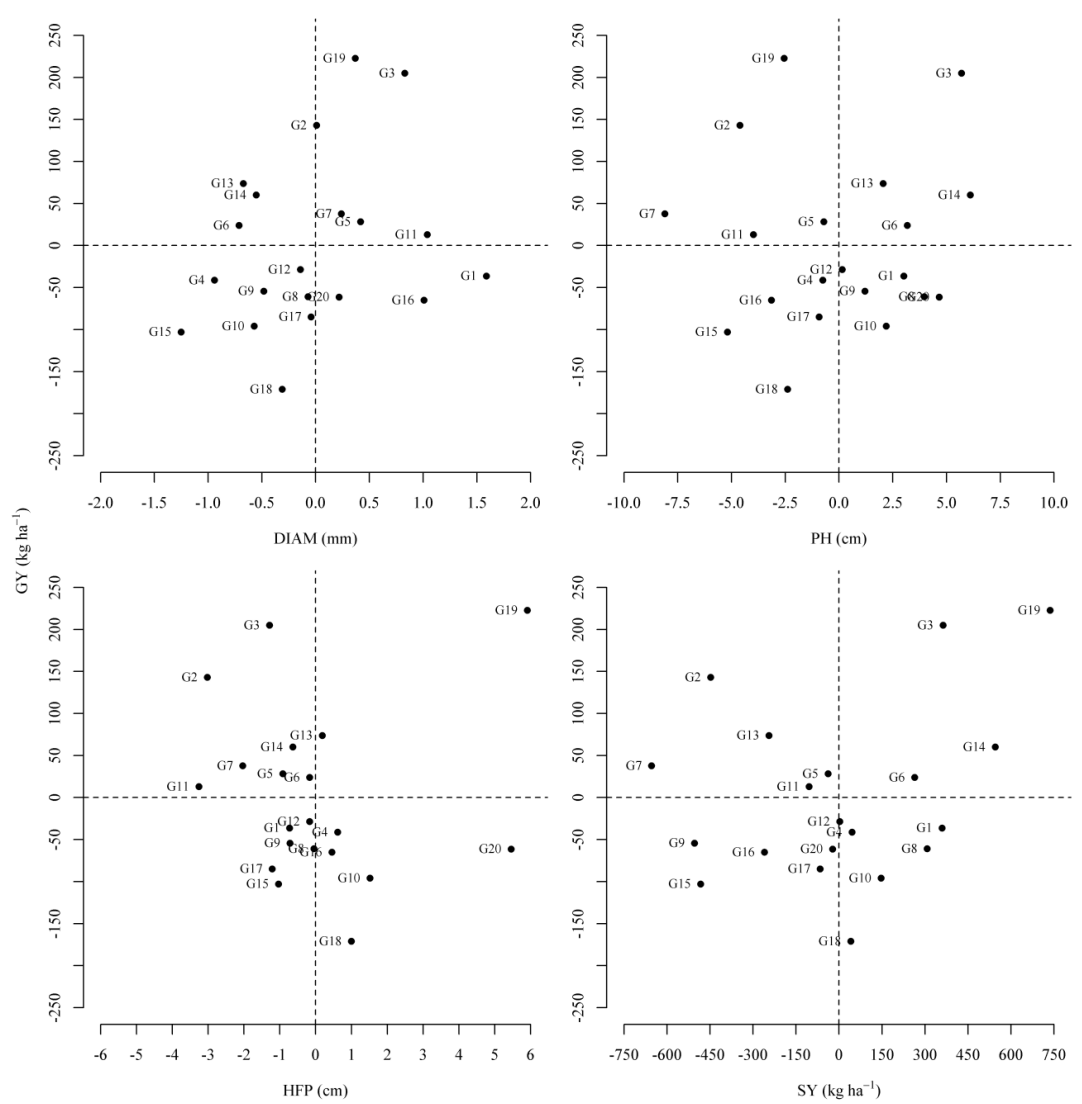

Figure 6. Genotypic values predicted (BLUP) for nine agronomic traits of the 20 Phaseolus vulgaris L. genotypes. Stem diameter (DIAM) in mm; height of first pod (HFP) in cm; plant height (PH) in cm; straw yield (SY) in $\mathrm{kg} \mathrm{ha}^{-1}$.

Among the 20 evaluated genotypes, seven (G2, G3, G7, G11, G13, G14 and G19) presented a superior genetic quality for the number of pods, number of seeds and grain yield. Based on the results, these genotypes are recommended for future crossings; however, the genotypes G3 (BLUP=204.66) and G19 (BLUP=222.39) occupied the first ranking positions, as they presented a superior performance in relation to the others for the grain yield attribute (Figures 5 and 6).

Notably, in the segregating populations, crossings involving G2 and G3 also show high contributions to GY (BLUP=142.70; 204.66). Moreover, gains are expected in NS (BLUP=5.08), $\mathrm{PN}$ $(\mathrm{BLUP}=0.92 ; \mathrm{BLUP}=0.42)$ and $\mathrm{GM}(\mathrm{BLUP}=1.16$; 1.06). In turn, the negative gains for $\mathrm{PH}$ (BLUP=$2.55)$ and PROT (BLUP $=-4.60)$ indicate that the improvement of one trait will be detrimental to the other, so that selection based on one of them is not recommended in these cases (Figures 5 and 6). Thus, the strategy of performing selection based on the evaluated parameters is indicated to single out promising genotypes.

The results of the multivariate analysis proved efficacious in the allocation of progenies into divergent groups as well as in the recommendation for crossings in future programs of bean breeding.

\section{Acknowledgements}

This study was supported by the Research

FAPES, CAPES, CNPQ, UFES. 


\section{Resumen}

C.M.O.M. Carias, J.H.S. Guilhen, T. S. Marçal, A. Ferreira, y M.F.S. Ferreira. 2018. Divergencia genética hacia la selección de progenitores de frijol prometedores a través de modelos multivariados mixtos. Cien. Inv. Agr. 45(3): 251-262 La variabilidad genética presente en el germoplasma de frijol (Phaseolus vulgaris L.) actualmente utilizada en la agricultura es la garantía más pronunciada de estabilidad de la producción y sustento humano en relación con este cultivo. En consecuencia, para mantener la mayor variabilidad disponible posible, este estudio tuvo como objetivo examinar la divergencia genética mediante análisis multivariante para identificar fuentes de variabilidad genética y permitir a los mejoradores reconocer las combinaciones genéticas con mayores posibilidades de éxito antes de que se realicen los cruces. El experimento se realizó en diseño de bloques al azar con tres repeticiones en el año agrícola 2015. Los caracteres agronómicos evaluados fueron: diámetro del tallo (DIAM) en mm; altura (ALT) en cm; cantidad de semillas (CS); porcentaje de proteína (PROT); altura de la primera vaina (APV) en cm; número de pod (NP); masa de grano por planta (MG) en g planta $^{-1}$; rendimiento de grano (RG) en kg $\mathrm{ha}^{-1}$; y rendimiento de paja (RP) en $\mathrm{kg} \mathrm{ha}^{-1}$. Para seleccionar los genotipos más divergentes, se analizaron 20 diferentes agrupando según el criterio de ligamiento promedio (UPGMA) usando la matriz de distancias euclidianas estandarizadas medias, y el análisis de componentes principales en base a los valores predichos mediante el modelo mixto multivariante. Los resultados obtenidos en este estudio revelaron un alto grado de divergencia genética y permitieron la asignación de las progenies en diferentes grupos, así como recomendaciones para cruces en futuros programas de mejoramiento de frijol.

Palabras clave: Análisis de conglomerados, Phaseolus vulgaris L, REM / BLUP, reproducción, variabilidad genética.

\section{References}

Barili, L.D., N.M. Vale, L.M. Moura, R.G. Paula, F.F. Silva, and J.E.S. Carneiro. 2016. Genetic progress resulting from forty-three years of breeding of the carioca common bean in Brazil. Genetics and molecular research: GMR, 15(3).

Coimbra, J.L. M., A.F. Guidolin, R.O. Nodari, H.T. Elias, L.D. Barili, N.M.D. Vale, and D.S. Rozzetto. 2009. Rendimento de grãos em feijão preto: $\mathrm{o}$ componente que mais interfere no valor fenotípico é o ambiente. Ciência Rural, 39(7).

Collicchio, E., M.A.P. Ramalho, and Â.D.F.B. Abreu. 1997. Associação entre o porte da planta do feijoeiro e o tamanho dos grãos. Pesquisa Agropecuária Brasileira 32:297-304.

Cruz Baldissera, J.N., J.G. Bertoldo, G. Valentini, M.M.D. Coan, D.S. Rozeto, A.F. Guidolin, and J.L.M. Coimbra. 2012. Uso do melhor preditor linear não-viesado (BLUP) na predição de híbridos em feijão. Bioscience Journal 28:395-403.
Cruz, C.D., and A.J. Regazzi. editora. 1997. Modelos biométricos aplicados ao melhoramento genético. v. 2. UFV.

De Faria, L.C., P.G.S. Melo, H.S. Pereira, A. Wendland, S.F. Borges, I.A. Pereira Filho, and L.C. Melo. 2014. Genetic progress during 22 years of black bean improvement. Euphytica 199:261-272.

De Resende, M.D.V. 2002. Genética biométrica e estatística no melhoramento de plantas perenes. Embrapa Informação Tecnológica, Colombo: Embrapa Florestas.

De Resende, M.D.V., and J.B. Duarte. 2007. Precisão e controle de qualidade em experimentos de avaliação de cultivares. Pesquisa Agropecuária Tropical 37(3).

De Resende, M.A.V., J.A. De Freitas, M.A. Lanza, M.D.V. De Resende, and C.F. Azevedo. 2014. Divergência genética e índice de seleção via BLUP em acessos de algodoeiro para características tecnológicas da fibra. Pesquisa Agropecuária Tropical (Agricultural Research in the Tropics) 44:10-1590.

Dos Santos, A.A.B., V.C. Ambrozio, M.A.A. Barelli, P.B. Da Luz, and T.S. Guimarães. 2017. Carac- 
terização da variabilidade genética de diferentes acessos de feijoeiro comum na região de Cáceres. Magistra 27:90-100.

Falconer, D.S. 1987. Introdução à genética quantitativa. Viçosa: UFV. 279p

FAO. 2009. How to feed the world in 2050. In: Rome: High-Level Expert Forum.

FAO. 2014. The State of Food and Agriculture: Innovation in family farming. Rome.

Fehr, W.R. 1987. Principles of cultivar development. Volume 1. Theory and technique. Macmillan publishing company.

Food Loss and Food Waste. http://www.fao.org, Food and Agriculture Organization of the United Nations, 2015. http://www.fao.org/food-lossand-foodwaste/en/ (Accessed 06 Oct. 2015).

Gilmour, A.R., R. Thompson, and B.R. Cullis. 1995. Average information REML: an efficient algorithm for variance parameter estimation in linear mixed models. Biometrics 1440-1450.

Gonçalves, D.D.L., M.A.A. Barelli, P.R.J.D. Santos, T.C.D. Oliveira, C.R.D. Silva, L.G.Neves, and P.B.D. Luz. 2016. Genetic variability of traditional germplasm of common bean in Caceres region, Brazil. Ciência Rural 46:100-107.

Londero, P.M.G., N.D. Ribeiro, E. Jost, S.M. Maziero, T. Cerutti, and N.L. Poersch. 2015. Genética dos teores de fibras insolúvel e solúvel em grãos de feijão. Revista Ceres, 56(2).

Lucena, R.S., and J.L.L. Dantas. 2017. Genetic divergence by means of morphoagronomic characters and fruit quality of papaya hybrids and lineages. Magistra 27:101-109.

Martinho Correa, A., and M.C. Gonçalves. 2012. Divergência genética em genótipos de feijão comum cultivados em Mato Grosso do Sul. Revista Ceres 59(2).

Nietzsche, F.W. 2000. Sobre la utilidad y los perjuicios de la historia para la vida.v. 249. Edaf.

Plans, M., J. Simó, F. Casañas, J. Sabaté, and L. Rodriguez-Saona. 2013. Characterization of common beans (Phaseolus vulgaris L.) by infrared spectroscopy: comparison of MIR, FT-NIR and dispersive NIR using portable and benchtop instruments. Food research international 54:1643-1651.

Prezotti, L.C., J.A. Gomes, G.G. Dadalto, J.A. Oliveira. 2007.Manual de recomendação de calagem e adu- bação para o Estado do Espírito Santo-5a aproximação. Vitória. Seeea/Incaper/Cedagro. 305p.

R Core Team: A language and environment for statistical computing. R Foundation for Statistical Computing, Vienna, Austria. 2015. http://www.Rproject.org. 2016. (Accessed 06 Oct. 2015).

Ramalho, M.A.P., J.D. Santos, and M.D.O. Zimmermann. 1993. Genética quantitativa em plantas autógamas: aplicações ao melhoramento do feijoeiro. Goiânia: UFG.

Rao, A.V., A.S.R. Prasad, T.S. Krishna, D.V. Seshu, and T.E. Srinivasan. 1981. Genetic divergence among some brown planthopper resistant rice varieties. Indian Journal of Genetics and Plant Breeding (The) 41:179-185.

Ribeiro, N.D. 2010. Potencial de aumento da qualidade nutricional do feijão por melhoramento genético. Semina: Ciências Agrárias 31:1367-1376.

Ribeiro, N.D., S.M. Maziero, M. Prigol, C.W. Nogueira, D.P. Rosa, and M.T.D.F. Possobom. 2012. Mineral concentrations in the embryo and seed coat of common bean cultivars. Journal of Food Composition and Analysis 26:89-95.

Silva, T.R.D.C.,A.T.D. Amaral Júnior, L.S.A. Gonçalves, L.S. Candido, C. Vittorazzi, and C.A. Scapim. 2013. Agronomic performance of popcorn genotypes in Northern and Northwestern Rio de Janeiro State. Acta Scientiarum. Agronomy 35:57-63.

Streck, E.A., G.A. Aguiar, A.M.D. Magalhães Júnior, P.H.K. Facchinello, and A.C.D. Oliveira, 2017. Phenotypic variability in genotypes of irrigated rice via multivariate analysis. Revista Ciência Agronômica 48:101-109.

Torga, P.P., P.G.S. Melo, H.S. Pereira, L.C. De Faria, M.J. Del Peloso, and L.C. Melo. 2013. Decomposition of the interaction of common black bean group genotypes with the environment. Agricultural Sciences 4:683.

Torres, F.E., P.E. Teodoro, E. Sagrilo, G. Ceccon, and A.M. Correa. 2015. Interação genótipo x ambiente em genótipos de feijão-caupi semiprostrado via modelos mistos. Bragantia 74(3).

Vivas, M., S.F. Silveira, A. Pio-Viana, A.T. AmaralJunior, G.A. Ferreguetti, and M.G. Pereira. 2015. Resistance to multiple foliar diseases in papaya genotypes in Brazil Crop Protection 71:138-143. 